\title{
A Thematic Literature Review about Academic Leadership Development: Exploring and Comparing Latin American with Non-Latin American Leadership Literature
}

\author{
Fernanda Kri \\ Universidad de O'Higgins, Chile \\ Shelleyann Scott \\ University of Calgary, Calgary, Canada \\ Donald E. Scott \\ University of Calgary, Calgary, Canada
}

\begin{tabular}{lr}
\hline Abstract & $\begin{array}{r}\text { Article } \\
\text { Info }\end{array}$ \\
\hline This report is part of the International Study of Leadership & $\begin{array}{r}\text { Article History: } \\
\text { Received }\end{array}$ \\
Development in Higher Education project (ISLDHE) project & January 09, 2020 \\
which is examining leadership development for university & Accepted \\
leaders. This paper presents an update to our original & March 30, 2021 \\
exploration of the literature about university contexts and & Keywords: \\
leadership development, but also compares the themes as they & Leadership, \\
relate to Latin American countries and those emerging from & Higher education, \\
other countries. We identified the skills that university leaders & Leadership \\
should have to appropriately manage the challenges of & development, \\
contemporary universities. We also report on themes & Leadership \\
pertaining to currently available leadership development & knowledge, \\
programs. The review showed a high coincidence in the skills & Skills and \\
required for leaders in Latin American contexts to those in & attitudes/attributes, \\
non-Latin American universities. We noted that the lack of & University \\
clarity in the characteristics and formats of optimal leadership & leadership, Latin \\
development programs were pervasive throughout both & America.
\end{tabular}


western and Latin American literature; however, there was a distinct lack of research on leadership and leadership development emerging from Latin America. One significant difference in Latin American leadership literature was the emphasis on senior leadership levels, whereas in non-Latin American countries, leadership and power were more distributed to decanal and head of department levels as well as senior leadership levels.

\section{Cite as:}

Kri, F., Scott, S., \& Scott, D.E. (2021). A thematic literature review about academic leadership development: Exploring and comparing Latin American with Non-Latin American leadership literature. Research in Educational Administration \& Leadership, 6(2), 378-430. DOI: $10.30828 / \mathrm{real} / 2021.2 .2$

\section{Introduction}

This paper emerges from the International Study of Leadership Development in Higher Education project (ISLDHE) which is focused on exploring the availability and effectiveness of academic leadership development (LD) with the intent to inform the design of optimal programming for heads of departments, deans, and leaders at the senior levels of universities. The ISLDHE research questions encompass: 1) How effective are current programs? 2) How can we optimally support our leaders' development to ensure increased leader-efficacy, success, and job fulfilment within dynamic university contexts, with a view to ensuring a nexus between theory and practice? 3) How should contemporary university leadership be conceptualized and theorized? and 4) How can these pragmatic and theoretical insights influence optimal LD programming?

In the early stages of this project the Canadian team undertook a literature review that explored the established knowledge base about the themes of university leadership in terms of their roles and 

6(2), June 2021, 378-430

responsibilities, leadership contexts, skills and capacity required by leaders, and suggested or actual LD programs (Scott et al., 2016b) in the English language literature. We did not originally set out to explore these themes in relation to particular countries, rather we examined all countries and research where these themes were present, so none were excluded. At that time, we found studies from: Australia, New Zealand, U.K., and the U.S. Our original literature review examined the knowledge base up to and including studies published in 2015. This current review encompassed the more recent literature from 2016 onward. Interestingly, we found there was more research from a broader range of contexts than previously, which was exciting to see that interest and research was growing in the area of leadership and LD in universities.

As the ISLDHE team expanded with new collaborators joining the project from different countries, we encouraged new members to undertake a literature review on leadership and LD trends and issues specific to their own national contexts. This was largely in acknowledgement of potential cultural differences in governance and institutional expectations for leaders, and to scope leadership development programs and approaches that were occurring in their institutions and countries and/or what LD was being suggested and why. Additionally, as many of our collaborators have varied discipline backgrounds (other than education and leadership), their knowledge of leadership and LD tends to be largely experiential. Consequently, undertaking a literature review provides a useful introduction to the leadership field in general, serves as a valuable foundation for contextualizing their project findings, and enable interesting insights with other national settings within the project. 
This paper resulted from a year-long "visiting scholar" collaboration between the Canadian co-chairs of the project and a new member from Chile. This collaboration provided opportunities to explore university leadership in Chile, and through her crossnational networks, other Latin American countries. As the co-chairs are Anglophones, this was a novel opportunity to explore the Spanish-based leadership literature and gain new insights into university leadership and governance, and LD in Latin American countries. Kri found leadership studies in the following Spanishspeaking countries: Argentina, Chile, Columbia, Cuba, Latin America (studies which drew upon all 20 countries), Mexico, and Venezuela. Through our collaborative literature search we found studies not only from: Australia, New Zealand, U.K., and the U.S., but now research was emerging from Europe, India, Indonesia, Ireland, Saudi Arabia, South Africa, and Sweden. This provided opportunities to compare and contrast the English language literature with the Spanish Latin American literature. We also examined the types (methodological) and scope of the research studies that were emerging on LD post our original foray into the literature as this had not been within our original review.

We found there had been a flurry of research in the late 1990s which focused on the complexities of leadership. Most of these studies emerged from the U.S. and U.K. contexts (Gmelch, 2015; Maghroori \& Powers, 2004; Montez \& Wolverton, 2000; Pounder, 2001; Wolverton \& Gonzales, 2000; Wolverton et al., 1998), but little research was emerging from the Canadian context (Acker, 2014; Eastman, 2006). This was an important point given that Canada has a very different higher education (HE) system due to it provincial rather than federal jurisdictional governance. There was a lull in research in the late 2000s, but interest ignited later in 2010 through 

6(2), June 2021, 378-430

2020 with research focused on leaders' skills and responsibilities and in LD within this ever-changing HE landscape (Dopson et al., 2019; Kenner \& Pressler, 2011; Martin, 2015; Isaac et al., 2009; Scholkmann, 2011; Wilkes et al., 2015) particularly pertaining to the reduction in funding to universities (Davies \& Thomas, 2009; Hodson, 2010). Much of the research identified the failure of leaders to adequately respond to the myriad of challenges facing them within this new ambit (Rosser et al., 2003; Werner, 2009) with many advocating LD (Carrick Institute for Learning and Teaching in Higher Education, 2008; DeZure et al., 2014; Nies \& Wolverton, 2000; Tang et al., 2013). Overall, the findings of our initial literature review revealed five main themes: leadership is important; the influence of contexts, change, and the challenges these represent to leaders; the importance of leadership theory to guide practice; and finally, LD is crucial to effective practice.

First, leadership is important. Formal leaders hold power over policy and procedures, workload allocation (Maclean, 2016), reward and recognition processes (Ramsden, 1998), vision and mission, motivation and wellbeing (Watts \& Robertson, 2011), and set the tone of a faculty. Indeed, they are pivotal to the faculty's teaching and research outcomes (Ramsden \& Martin, 1996), financial sustainability (Shahmandi et al., 2011; Wolverton \& Poch, 2000), culture (Vatanartiran, 2013), and organizational reputation (DeFleur et al., 2010; Weerts \& Sandmann, 2010). Therefore, effective leadership is crucial to institutional viability.

Second, contexts, change, and the challenges these represent for leaders. Leading the academy has always been challenging, but there have been many international influences that have altered university leaders' responsibilities (Davies \& Thomas, 2010; Scott et al., 2016a; 
Wolverton et al., 2001). Change influences include: globalization; global economic trends, and the rise of neoliberalism-the economic principle of privatization rather than services as a public good (Apple, 2006, 2013; Osei-Kofi, 2012); technology, the rise of the knowledge economy (Marginson, 2009); migration of peoples; and national/international competition (Marginson \& van Der Wende, 2007a; Marginson \& van der Wende, 2007b; Rajagopal, 2009; Toakley, 2004); and others. These changes meant less funding for universities (Doyle \& Delaney, 2009; Eastman, 2006; Marginson, 2000, 2003, 2006), greater accountability for outcomes (Almayali \& Ahmad, 2012; Clark, 2009; Pounder, 2001; Rosser et al., 2003), increases in fee-for-service programs, international student markets (Webber \& Scott, 2008), and university competition (Cudmore, 2005; Marginson, 2009) to name a few. Consequently, leaders must rise to these challenges, become change agents (Northouse, 2019; Kouzes \& Posner, 2012), be enterprising and entrepreneurial (Alstete, 2014), all while supporting their staff to make the adjustment to this changed academia.

Third, leaders' influence on academic culture and outcomes. Universities are unique workplaces in that their outputs are in human capital and knowledge production (Marginson, 2009). Their organizational cultures are shaped by academic reward systems (Horn, 1999; Wyman, 1973), philosophies (Kligyte \& Barrie, 2014), collegial governance processes (Stensaker \& Vabø, 2013), academic empowerment (DeBoy, 2015; Opstrup \& Pihl-Thingvad, 2016), job security (Mysyk, 2001), and also by leaders' approaches (Bratianu \& Pinzaru, 2015). The touchstones of academic identities are supreme research prowess (Smyth, 2017), teaching excellence (Prosser \& Barrie, 2000; Prosser \& Trigwell, 1999; Trigwell \& Prosser,1991), academic freedom (Messier, 2017), and collegial/shared governance (Pennock et al., 2016). Destructive and toxic leadership approaches 

6(2), June 2021, 378-430

damage academic cultures and deleteriously impact productivity (Thoroughgood, 2018; Ramírez \& Hyslop-Margison, 2015; Webster, 2016). Hence, leaders must meet accountability expectations for quantity and quality outcomes, while simultaneously creating constructive workplaces.

Fourth, the importance of leadership theory to guide practice. Even though the leadership literature abounds with theories that capture valuable and important dimensions of leadership, few LD studies used leadership theories other than in passing. Transformational leadership theory (Kouzes \& Posner, 2012, 2019) and authentic leadership theory (Avolio \& Gardner, 2005) were the most frequent theories applied to university leadership, but these were rarely mentioned in LD programs. This was likely due to these theories' focus on relationship- and trust-building as an antidote to destructive or toxic leadership (Smyth, 2017; Thoroughgood, 2018; Webster, 2016). Curiously, few advocated for including leadership theory into LD programming (Dopson et al., 2019). Likewise, there was no mention of developing an evidence-based leadership theory specific to $\mathrm{HE}$, thus our project's aim to potentially inform theory was filling a gap in the literature.

Fifth, leadership development is crucial to effective practice. Most authors advocated for LD to promote particular knowledge, skills, or attitudinal development, and there were calls for the establishment of more extensive, systematic, and more effective LD (Nica, 2013; Ortrun \& Louw, 2014). Even so, few outlined optimal program content, processes, and/or delivery (Morris \& Laipple, 2015; Shahmandi et al., 2011; Shahmandi et al., 2012). The most prevalent LD was mentoring or executive coaching, but, although valuable, they were reported as expensive, time-consuming, and difficult to 
establish and sustain (Baartman, 2011; Commodore et al., 2016; DeZure et al., 2014; Green \& Ridenour, 2004; Kleihauer et al., 2012; Nies \& Wolverton, 2000). Consequently, LD was confirmed as an important research topic (Erkutlu et al., 2011). Specifically, more research was needed to identify what knowledge, skills, attitudes, and delivery formats, were needed for effective leadership, and efficacious and authentic leader development.

From this earlier review, our parameters for this "update" review included universities new functions (the context), leadership skills and capacities (to flow into LD content programming), and studies about LD (for delivery/formats information) (see Table 1).

Table 1.

Literature Analysis Framework

Framework for the identification of leadership development needs at the universities

1. New function and leadership roles

1.1. Universities

1.2. Leaders

2. Leadership skills

2.1. Theoretical

2.2. Case studies (pragmatic-leaders' insights)

3. Leadership development

3.1. Identification of the necessity for programs

3.2. Program descriptions or evaluation

1. Universities' new functions: This explored the contextual changes specific to both senior leadership and middle level leaders, which were categorized as: (1.1) Universities - institutional concerns and context; and (1.2) Leaders' concerns.

2. Leadership skills and capacities essential for successful leadership. These were defined theoretically, based on the literature, a review of leadership theories, or from pragmatic cases drawn 

6(2), June 2021, 378-430

upon leaders' experiences. Therefore, the categories were identified as: (2.1) Theoretical and (2.2) Case studies.

3. Leadership development referred to the explicit mention of LD programs specific to university academic leaders. Two categories were identified: (3.1) Leaders' needs, and (3.2) Program descriptions and/or evaluations of programs. Thus, 3.1 related to proposed program content whereas 3.2 related to actual programming.

\section{New Functions and Leadership Roles Universities}

Our updated literature review affirmed previous findings that "universities globally are facing novel challenges, as they become larger, more complex and multi-functional organisations" (Dopson et al., 2019, p. 219). For example, neoliberalism, globalization, and the marketization of $\mathrm{HE}$, have radically impacted the functioning of universities throughout the world and also influenced leadership roles (Apple, 2000, 2006, 2017; Marginson, 2003, 2006; Smyth, 2017). Indeed, we identified that these contextual factors are now more widespread, impactful, and are revisioning academic work and leadership - not for the better. For example, Smyth (2017) identified "zombie leadership" leads to "pathological organizational dysfunction" (p. 5). He explained this as leaders and administrators taking an unquestioning stance in their acceptance of the neoliberal agenda. He indicated this dysfunction has led to "enormous suffering and degradation" (p. 6) for academics and negative impacts on academic careers, workload, and mental health and wellbeing.

Of course, the realities of each country are different and these influences have occurred with varied emphases and timeframes. Even so, it was possible to identify important similarities and differences in the HE sectors across different countries. For example, 
neoliberal principles have a stranglehold in western nations (e.g., U.K., U.S.A., Australia), but in recent times, neoliberalism has seen some reversals in Chile with community protests about equal access to HE, the burden of student fees, and so on (Rodriguez-Videla, 2018). So, while universities around the world seemed to face the similar contextual challenges, the stages of intervention, strategies, and solutions were different in various national contexts (BerbegalMirabent et al., 2015; Marginson, 2002).

Over the past two decades, neoliberalism has led to decreases in public funding (Apple, 2017), and greater competition in job markets leading to increased demand for university qualifications for social mobility (Universities UK, 2016). Less government funding has forced universities to economize and to seek new revenue sources (Cleverley-Thompson, 2016; Hempsall, 2014). For example, in Australian, U.K., and U.S., international students have become a lucrative new market (Marginson, 2002), whereas in Latin America, industry partnerships have been sought to create entrepreneurial opportunities (Berbegal-Mirabent et al., 2015). In Latin American countries (e.g., Chile), increases in local students was in response to government policies promoting equity and social mobility (Bradley et al., 2017). However, when students present with varied abilities and preparation this increased teaching complexities.

For two decades, international students have been an essential source of funding for many western nations (Marginson, 2002, 2009). However, overreliance on this revenue source has created a pivotal sustainability risk factor. This was demonstrated recently in Australia and the U.K. where HE sectors have experienced a "catastrophe" with the outbreak of the COVID-19 pandemic. Overseas students have been unable to cross borders into Australia and the U.K., which 

6(2), June 2021, 378-430

has caused a collapse in usual university operations (Beard, 2020; Packham, 2020; Robinson, 2019). It is yet to be seen if the impact of COVID-19 will result in a re-assessment of government funding models for HE sectors around the world, or will this cause a contraction in many HE sectors?

A worldwide trend has been for greater accountability and transparency in the use of resources (Carballo, 2019; Floyd \& Preston, 2018; Hodson, 2010; Preston \& Floyd, 2016). Quality assurance (QA) systems with emphases on ranking, metrics, and performance measurement generate new operational units to monitor, report, and manage these processes. These QA systems are crucial for proving quality, marketing, and for ongoing funding, but add additional complexities for leaders (Herbon \& Vivas, 2015). Another powerful form of accreditation has emerged from industry demands, wherein industries have influenced university curricula to assure graduate employability (de Paor, 2016; Gigliotti \& Ruben, 2017; Ruben et al., 2018).

Globalization and the integration of technologies, for operations, teaching, and engaging partner organizations, were newer challenges for universities particularly in Latin America (Cifuentes \& Vanderlinde, 2015; Cleverley-Thompson, 2016; Ruben et al., 2018). The extent of technological integration in Latin American countries was different to western nations due its incipiency in these contexts.

Internationalization was a newer theme in Latin America, where its purpose was to meet the expectations of quality assurance/rankings metrics (Huerta-Riveros \& Pedraja-Rejas, 2019; Ortega \& Freites, 2017; Sanchez, 2016). However, in Australia and other western contexts, some argued this was simply applying an 
educational "quality" rationale to a pragmatic funding imperative (Marginson, 2002, 2006). So, how do these contextual changes to university functions influence leaders' responsibilities?

\section{Leaders' Responsibilities}

Previously, leaders' roles and responsibilities related to coordinating teaching and research activities within the university (Wolverton et al., 2001). Leaders' responsibilities are now more complex, diverse, and more externally-oriented (Davies \& Thomas, $2009,2010)$. For example, contemporary leaders have major decisionmaking responsibilities (Morris \& Laipple, 2015) and these have farreaching impacts. For example, in Canada, leaders must manage large casualized (and fragmented) academic workforces (Jones, 2013). Their external focus is frequently linked to funding, where leaders must be more entrepreneurial and network with external stakeholders - universities, communities, industries, and business sectors (Bradley et al., 2017; Cleverley-Thompson, 2016; Preston \& Floyd, 2016). This was similar to the Latin American context with its emphasis on public engagement and outreach; however, in Latin America this is the purview of senior leaders, not deans (Lopez, 2013; Vega et al., 2015).

Another challenge linked to neoliberalism is the need to raise faculty's performances in national/international rankings, and to establish evaluation mechanisms to track ranking and performance metrics (Lamm et al., 2018).

With these new complexities, "heroic" leadership styles were reported as inappropriate; rather, shared or distributed leadership (Wang \& Sedivy-Benton, 2016), transformational (Kouzes \& Posner, 2019), and authentic leadership (Avolio \& Gardner, 2005) were identified as more viable for contemporary universities. These were 

6(2), June 2021, 378-430

advised due to their enhanced relational and consultative approaches. Jones et al. (2017) indicated distributed leadership was useful due to the scope of contemporary leadership roles and the complexities. Indeed, in the Latin American case, there is a distinct need for shared leadership (Carballo, 2019; Cardiel, 1999; Vega et al., 2015), particularly given the supreme power of the superior authorities (i.e., the rector).

\section{Leadership Skills}

In many universities in the world, leaders are generally selected based upon research prowess, not necessarily for their management and leadership skills (Wang \& Sedivy-Benton, 2016; Wolverton \& Gonzales, 2000; Wolverton \& Poch, 2000). This criterion (i.e., scholarship) can create a disconnect in preparation and skill development for effective leadership (Tang et al., 2013; Kouzes \& Posner, 2013; Wolverton et al., 2007).

In exploring requisite leadership skills, we found two main approaches: 1) theoretical discussions of useful skills, and 2) pragmatic accounts where leader-participants provided insights from the field. Curiously, we found most Latin American literature had a theoretical orientation with only small-scale case studies, whereas western literature tended towards empirical studies (including qualitative and/or quantitative) with larger participant numbers.

\section{Theoretical Insights}

Although there are many theoretical studies about leadership skills and styles, there were few directly related to HE contexts. Wang and Sedivy-Benton (2016) explored the differences in HE contexts, cultures, and how leaders are appointed from the academic ranks to explain why many leadership theories do not apply. Thus, they 
posited requisite skills to be leading people, managing operations, and developing positive cultures.

Bradley et al. (2017) undertook a theoretical analysis of Australian middle level leaders and identified the complexities related to navigating academic and non-academic staff interests, and mediating the competing demands of senior leaders (superordinates) and academics (subordinates). Therefore, consultation was important as top-down approaches were not always effective. They also noted difficulties in balancing administration and academic activities (setting and balancing priorities).

In the Latin America literature, Ortega and Freites (2017) defined university management, and detailed the complexity of university functions. They noted the need for transformational leadership, given the global and local realities facing Latin American universities. Their theoretical construct for university management included: teaching, research, community and cultural service (networking and communication), and administration (managing people and processes). Falcón (2016) presented a management model for Venezuelan universities, while Sanchez (2016) posited the importance of strategic planning and management.

With a greater focus on leadership (and not administration) Pedraja-Rejas et al. (2018) established the relationships between leadership style, academic culture, and the quality of the institution and discussed skills such as communication, interpersonal capacities, and relationship building. Likewise, Carballo (2019) reflected on why shared leadership (collegiality and consultation) was better than individualized leadership in HE. Carballo reported that the vast majority of LD programs focused on personal skills, but recommended a shift towards shared leadership. Even so, these 

6(2), June 2021, 378-430

authors did not provide specifics about proposed LD programs or how shared leadership could be promoted.

\section{Case Studies}

Among the pragmatic studies, there was considerable variation in participants (e.g., deans, vice chancellors, etc.), whereas in the Latin American cases they referred more to senior leaders (e.g., rectors) or did not differentiate between leadership levels.

Franken et al. (2015) discussed middle level leadership in Australian universities, while Hempsall's (2014) study included institutions in Australia, U.K., and the U.S. These studies showed the need for distributed and transformational leadership, and emphasized the importance of relationship-building skills and the capacity to build trust. Vilkinas and Ladyshewsky's (2014) Australian study about academic directors (middle level leaders) identified: knowledge and experience of the program and discipline, marketing skills, interpersonal and communication skills, and the ability to influence others (persuasiveness) as important to leadership performance.

Morris and Laipple's (2015) American study established that leaders (e.g., academic deans, directors, associate deans, and department chairs) who had taken courses in business administration, human resources, and leadership, felt more prepared than those who had not. The skills they identified as important were: the ability to set clear expectations, consistency, and proactivity, meeting commitments (reliability), and having a focus on critical activities (prioritization). Moreover, Cleverley-Thompson (2016) examined the self-reported entrepreneurial orientations of American academic deans, and highlighted team-building and proactivity as very important. Similarly, in Sweden, Söderhjelm et al. (2018) iterated the 
importance of team-building at the departmental level and described a group training intervention as academic leadership.

In seeking to clarify key leadership skills, we also found research from non-western contexts such as India, Indonesia, and Saudi Arabia (Alghamdi et al., 2016; Choudhary \& Paharia, 2018; Jooste \& Frantz, 2017; Ngo et al., 2014). In the Saudi context, Alghamdi et al.'s (2016) study established key skills as: personal and interpersonal capabilities, self-organization, flexibility and responsiveness, strategy, diagnosis, and empathy. In India and South Africa, the importance of teamwork, decision-making, adaptability to change, visioning, communication, and contextual understanding were highlighted (Jooste \& Frantz, 2017; Ngo et al., 2014). Ngo et al. (2014) emphasized value-based leadership approaches, such as consultation, consensual goal-setting, team leadership, and trust-building, as important for Indonesian deans.

In the Latin American literature, leadership skills were largely those of the rectors. Ganga et al.'s (2018) study of Ibero-American universities (a survey of 800 leaders (1) rectors, vice-chancellors, provosts, and (2) career or program managers) identified the importance of effective leadership in achievement of institutional objectives. They highlighted the importance of team-building, cognitive flexibility and openness to the team's suggestions, navigating competing interests (fairness), and being trustworthy. Likewise, Fabela-Cárdenas and Garcia-Treviño's (2014) Mexican study presented a model of influential factors for educational quality. They highlighted cognitive capacities such as analysis, problem-solving, and fiscal entrepreneurship, as well as relational abilities such as capacity building of others and networking with industry partners. Similar to Ganga et al., (2018), Fabela-Cárdenas et al. (2014) found that the 

6(2), June 2021, 378-430

power and influence of rectors was important, but these were not considered the most relevant. Indeed, faculty/school management, curriculum design, infrastructure, and the teaching and learning strategic plan were predominant for success. On the other hand, Torres and Torres' (2015) Mexican study identified that mechanistic (or bureaucratic) management (over controlling management) was detrimental to teacher development and highlighted the importance of shared leadership and collaboration.

Aligned with Ganga et al.'s (2018) findings, Contreras et al. (2018) indicated that university senior leaders' skills were fundamental to effective management, particularly given current complexities. They analyzed the pre- and post-graduate training of directors of Chilean universities and found their backgrounds were in the social sciences, technology, or engineering not in leadership or management which highlighted their lack of preparation for leadership. Raschio et al.'s (2019) analysis of two Argentinian rectors' leadership experiences emphasized the importance of: strategic planning, networking, teamworking, and understanding the institutional culture. They asserted that leaders needed adequate training, ideally prior to assuming leadership positions. Cifuentes and Vanderlinde's (2015) Columbian study reiterated the importance of strategic planning particularly related to leading technological innovations. de la Garza et al.'s (2017) and Gonzalez-Rodriguez's (2018) Mexican studies (quantitative and qualitative, respectively) focused on the personal and interpersonal skills of leaders and de la Garza et al. (2017) linked these to quality leadership. They emphasized the importance of making difficult decisions, engaging in confident risk-taking, and taking responsibility for their decisions. They also noted the importance of using interpersonal skills to mediate competing stakeholder perspectives; and other valuable skills were self-organization, communication skills, 
and the ability to build trust. Gonzalez-Rodriguez's (2018) Jalisco and Mexico City study about rector-level leadership, established a typology of leaders citing the following skills as pivotal: decisionmaking, management capacity, communication skills, visioning, and attachment to institutional values. Table 2 displays a synthesis of the main skills found in this literature review.

Table 2.

Synthesis of the Main Leadership Skills and Capacities noted in the Literature Review

Comparing Latin American \& Non-Latin: Expected Capacities of University Leaders

Latin American literature

Cognitive capacities

Strategic planning and management (5)

Make decisions (4)

Networking (3)

Understands the culture of the institution (3)

Understand the global and local context (2)

Lead the introduction of technologies (2)

Taking responsibility for their decisions (1)

Conflict management (1)

Risk management (1)

Visioning (1)
Difficult decisions and conflict management (1)

\section{Non-Latin American literature}

\section{Cognitive capacities}

Strategic planning and management (3)

Make decisions and focus on critical activities (1)

Diagnosis of needs and direction (1)

Ability to set clear expectations (1)

Understand the context (2)

Visioning (1)

Marketing (1)

Responsiveness (1) 

6(2), June 2021, 378-430

\section{Affective-related skills}

Self-organization (3)

Team-working (2)

Communication skills (2)

Understands and meditates competing

stakeholder perspectives (2)

Ability to build trust (1)

Working constructively (1)

\section{Affective-related skills}

Self-organization (5)

Team-building and team-working (2)

Communication skills (2)

Manages the tensions of the differing demands and expectations (1)

Navigating academic and non-academic staff interests (1)

Relationship-building and capacity to build trust (1)

Proactivity (3)

Interpersonal skills (2)

Flexibility and adaptability to change (1)

Consistency and meets commitments (1)

Empathy (1)

Ability to influence peers (1)

Balance in administration and academic activities (1)

Confidence in risk-taking (1)

Note: These skills and capacities have been presented in order of frequency and/or were prioritized according to this updated review. We have presented the Latin American skills/capacities as they align with the original skills/capacities. Where skills/capacities are presented alone, this indicates these were not articulated in the other data set.

Affective-related skills - this denotes skills or capacities which influence emotions and organizational culture.

Cognitive capacities - these indicate skills or capacities which require cognition, understanding, critical thinking, and/or identifying relationships and complexities.

Latin American Countries - this encompassed leadership literature from Argentina, Chile, Columbia, Cuba, Latin America (studies which drew upon all 20 countries), Mexico, Venezuela.

Non-Latin American Countries - Australia, Europe, Ireland, New Zealand, United Kingdom, U.S., South Africa, Sweden (and other countries which are not considered part of the West, and are not part of Latin America - i.e., India, Indonesia, and Saudi Arabia). 
Overall, across both the western and Latin American literature, the cognitive-related (thinking/mental) skills that were most frequently cited included strategic planning and management processes; and surprisingly, the capacity to make decisions and to problem solve. Decision-making was also linked to making difficult decisions especially during a crisis. Less surprising was the need for leaders to understand the context in which they operated which was also frequently linked to making good decisions. In the Latin American context, understanding the culture of the institution and the capacity to lead the introduction of technology were also important cognitive capacities. In terms of affective-related skills (emotions), the leaders' capacity to organize themselves was the most frequently cited skill. Team-working, team-building, communication, and interpersonal skills were also deemed important and highly inter-related.

It was curious that there was so much alignment between the skills and capacities cited in the Latin American literature to that of other countries, given differences in cultures and context it may have been expected to see a shift in requisite skills and capacities. The main differences that appeared in the Latin American literature revolved around: networking (3), understanding the culture of the institution (3), leading the introduction of technologies (2), taking responsibility for their decisions (1), and confidence in risk-taking (1). These will be interesting dimensions to explore in the next stage of our project in Chile (and with selected Latin American partners) to identify if there are other cultural factors that are influencing the need for these skills and capacities. When examining the more westernized contexts, there appeared to be greater emphasis on the affective-related skills such as: interpersonal skills (2), flexibility and adaptability to change (1), consistency and meeting commitments (1), empathy (1), and ability to influence peers (1). Many of these, influence the leaders' capacity to 

6(2), June 2021, 378-430

build trust and are directly linked to the literature on culture and destructive forms of leadership. This raises the question of whether negative leadership is more prevalent in westernized contexts? Again, another interesting dimension to explore in subsequent phases of our study.

\section{Leadership Development}

Arguably, given the emphasis of this literature review to promote our understandings of leadership development (LD) content and delivery, this section is probably the most pertinent to our study. We found LD was prevalent in universities, but frequently for undergraduate students, non-academic managers, or in business. There were few studies related to academic LD, but happily this topic appears to be drawing more interest (Alghamdi, 2016; Commodore et al., 2016; Gigliotti \& Ruben, 2017; Lamm et al., 2018; Mattar et al., 2018; Morris \& Laipple, 2015; Preston \& Floyd, 2016; Ruben et al., 2018; Söderhjelm et al., 2018). This reinforced our earlier review (Avolio \& Gardner, 2005; Baartman, 2011; DeZure et al., 2014; Hempsall, 2014; Isaac et al., 2009; Nica, 2013; Ortrun \& Louw, 2014) that LD appears to be recommended to: 1 ) address the complexity of university contexts, and the new functions of universities as a result of neoliberalism impacts, globalization, and the massification of university education; 2) provide support for leaders who require new knowledge, skills, and attitudes for their leadership roles; and 3) to overcome toxic or destructive leadership approaches which damage organizational cultures and employee's productivity. Reinforcing our previous findings, this updated review revealed a lack of detail about program design, content, or delivery. Indeed, there were only a couple of papers which presented program evaluations which offered specific details of programs (Alghamdi, 2016; Lamm et al., 2018). 


\section{Identification of the Necessity for LD Programs}

The literature affirmed that LD was necessary for effective and relational leadership (Avolio \& Gardner, 2005; DeZure et al., 2014; Dopson et al., 2019; Erkutlu et al., 2011; Hamlin \& Patel, 2017; Kenner \& Pressler, 2011). Indeed, Dopson and her colleagues (2019) identified that more research is needed into LD, into designing systematic and sustained LD, for including a stronger theoretical basis into programming, and to evaluate LD programs.

An important issue in leadership within HE is that leaders are frequently appointed from within the academy. However, in some in private institutions, the leaders are administrators appointed by the owners (Hamlin \& Patel, 2017). In the latter case, being a leader in HE was more likely to be a leadership career pathway (as opposed to an academic or researcher pathway) for which there are formal LD programs (Lamm et al., 2018). Consequently, it is to be expected that leaders who have received academic preparation (to become a scholar or university teacher) may not have the knowledge and skills for leadership unlike those whose career pathway is leadership and management. Thus, for those who are initially scholars selected for leadership there is a greater need for LD, as this role is very different to that of scholar or teacher.

In the U.K., Preston and Floyd (2016, Floyd \& Preston, 2018) took a retrospective perspective and explored what LD associate deans had experienced. Over half $(60 \%)$ of respondents reported having little or no training, while $24 \%$ indicated that their LD experiences had been "sporadic and unsatisfactory" (p. 276); hence, programs needed to be more relevant to leaders' roles and their participants wanted "informal peer group learning" (p. 276). Similarly, Hamlin and Patel's (2017) comparative French-English 

6(2), June 2021, 378-430

university leadership study, examined positive and negative leadership behaviors and concluded LD programs were important to overcome negative leadership. They did note though that existing programs (primarily in business schools) were inadequate and informal programs were also needed. Stensaker and Vab (2013) recommended LD programs be matched with universities' strategic plans to ensure that leaders' preparation and resourcing of programs were aligned to ensure institutional outcomes could be met. Most articles recommended a range of skills for optimal leadership, many of which were identified in the skills section of this paper. Additionally, Franken et al. (2015), Lamm et al. (2018), Mattar et al. (2018), and Morris and Laipple (2015) all advocated for contextualized and individualized LD. Mattar et al. (2018) emphasized coaching as an optimal approach because coaches encouraged leaders to engage in meaningful problem-solving and to assist in leader-identity development through guided self-reflection.

We found only two papers on LD from the Latin American context (Aristimuño \& Guaita, 2011; Moreno \& De Armas, 2018). These studies reported on essential leadership characteristics and recommended LD. However, again these did not elucidate content or delivery of programs.

\section{Program Designs}

From this updated review and our earlier one, authors recommended both formal and informal programming options to allow greatest flexibility for leaders. In a study conducted in across Australia, U.K., and U.S., Hempsall (2014) showed that there was considerable variability in LD programs and indicated the need for greater consistency and integration within each institution. Bradley et al. (2017) identified two types of Australian LD programs: formal 
training and experiential learning. The formal programs covered: mentoring, networking, understanding the macro context, leadership skills, and active and reflective leadership. Experiential learning consisted of on-the-job learning and learning from critical incidents, although we would argue that mentoring and networking are also experiential. Preston and Floyd's (2016; Floyd \& Preston, 2018) U.K. study found that the training associate deans received was insufficient and largely focused on managerial tasks rather than on leading such as: budgetary training, university systems and procedures, chairing meetings, human resource and staff management, strategy, and time management.

Morris and Laipple's (2015) large-scale, quantitative study (i.e., 1,515 U.S.A. university administrators) found that leaders who had taken courses in business administration felt more prepared for their administrative role. However, the main LD strategies were: seeking advice from senior colleagues, professional reading about administration and leadership, mandated seminars/workshops, external seminars, and/or consultation services.

The U.S. literature was quite varied given the variance in university types and state differences. Jaffe (2017) analyzed two LD programs for aspiring leaders in two U.S. universities. The content included: organizational policies, structures, and processes; resource allocation and budgeting; critical issues in HE; project development; and use of technologies. Similarly, Ruben et al. (2018), and Gigliotti and Ruben (2017) discussed their two-year LD program at Rutgers University which focused on: "1) leadership, organizational, and communication theory and practice; 2) professional and leadership development concepts and best practices; and 3) an inventory of contemporary challenges and opportunities in the U.S. Higher 
education in general, and Rutgers University in particular" (Ruben et al., 2018, p. 243). Another U.S. LD program was LEAD21 which appeared to be a significant national program. This was a nine-month program focused on: leading change, collaboration, conflict management, and effective communication. Lamm et al. (2018) conducted a 'three-generation of participants' (i.e., 255 participants) evaluation of the LEAD21 program to explore its effectiveness in developing leaders' change leadership. They reported success in increasing leaders' change agency, however, their evaluation methodology and how the program influenced change agency was not elucidated. In Saudi Arabia, Alghamdi et al. (2016) reported on the Academic Leadership Center which provides LD to university leaders. They found that leaders preferred learning and teaching conferences, HE leadership seminars, and "on-the-job" learning. Seale and Cross (2016) noted many South African universities do not have strategic approaches to LD and presented a LD framework to address this deficit. Their framework considered the new functions of university deans, especially contextual factors, leadership capacity, and "leadership capital" (i.e., leaders' prior preparation).

Despite this review, it was not possible to definitively establish which were the most appropriate programs and content for leadership preparation. While we found similarities in requisite skills, the best way to achieve the development of these remained undetermined. There was also a lack of detail about what form of LD delivery was optimal. There was also no information about whether cultural context influenced LD processes or ideal delivery. In the Latin American literature, we did not find any articles related to LD programs or evaluations. Therefore, LD remains unchartered, but important, territory within the Latin American context. 


\section{Discussion of Future Research Dimensions}

In the literature reviewed both previously and in this updated review, we observed that many universities have been similarly influenced by change throughout the world. For example, the need for entrepreneurship to establish new sources of funding due to governments' reduction in support; the rise of greater accountability and new quality assurance systems; the increase of students entering universities, many of whom have complex learning needs; the integration of technologies; globalization and internationalization; and the need for greater alignment with industry's expectations for graduate capacities; are new challenges that universities and their leaders must face (refer to Appendix A for a summary). An important point for later stages of the study will be to explore cultural and contextual variation in how these change agenda are enacted in different national settings.

This updated review emphasized the contextual complexities for leaders and universities. Given the new functions and contextual factors we found, we noted that contemporary leaders must acquire different skills to those of their predecessors. We did find cultural differences between the Latin American HE situations to universities in Australia, Europe, North America, U.K., the Middle East, and South Africa, although in all cases the need for new leadership skills remained. One clear difference was that in most Latin American universities, leadership was focused predominantly on the "superior authorities" - the rector level - rather than at the dean or associate dean level which was more prevalent in the other national contexts (Contreras et al., 2018; Fabela-Cárdenas et al., 2014; Ganga et al., 2018; Raschio et al., 2019). This may explain why in Latin America, authors advocated for shared/distributed leadership (Carballo, 2019; Cardiel, 1999; Vega et al., 2015). Even so, these same authors noted the 

6(2), June 2021, 378-430

difficulties of shared/distributed leadership due to the supreme authority of the rectors, and potentially represented a conundrum where one leads to the other and vice versa. Despite the differences in where power and control were vested, our analysis revealed there was alignment related to the skills needed for effective leadership across the different countries represented in the review (please refer to Appendix B for a summary of these essential leadership skills and capacities). Indeed, the dearth of literature about LD programs in the Latin American case indicated that this was an important area of study. It will also be interesting and important to gain insights into any further cultural, system, and contextual differences as we move forward with this study in Chile and other Latin American contexts.

Similar to our earlier review, we observed frequent calls for LD because of the complexities of contemporary academic leadership. Most also indicated that preparation for scholarship was insufficient and different to that required for leadership (Avolio \& Gardner, 2005; DeZure et al., 2014; Dopson et al., 2019; Hempsall, 2014). Despite the consensus on the need for LD programs, few papers deepened the themes or reported on optimal methodologies that programs should encompass for maximum impact (Dopson et al., 2019; Hempsall, 2014). Unlike our previous review, in this review we found a few established programs that provided some detail and had been established long enough to warrant evaluation (Alghamdi et al., 2016; Bradley et al., 2017). The duration of these programs ranged between nine months to two years, however, even though these programs appeared to be successful, the viability of protracted programs would need to be considered given how time-poor leaders are. Therefore, optimal delivery approaches (while considering program duration) are worth studying to ensure viability for busy leaders. For a summary of our LD findings please refer to Appendix C. 
An aspect that was not overtly addressed within the limited literature on existing LD programs was if the content of LD should vary respective of career stage. That is, should the content be different for aspirants as opposed to novices or experienced leaders? This variability in LD content according to career stage was an aspect that was established in the International Study for the Preparation of Principals (ISPP) (Webber et al., 2014; Webber \& Scott, 2013). It also raised the question as to whether more managerial-oriented content would be more useful at the associate dean level and more leadership-oriented content should be aimed at deans and senior leaders such as rectors, vice chancellors/presidents, and presidents. However, Preston and Floyd's (2016; Floyd \& Preston, 2018) study seems to counter this proposition as associate deans did not find the management-oriented LD all that useful.

Another curious aspect to emerge from both our previous and current literature reviews was that there was almost no mention of leadership theory (Avolio \& Gardner, 2005; Kouzes \& Posner, 2019) either as a suggestion for inclusion into LD or in program designs. Some authors discussed the importance of reflection and formation of leadership identities, but they did not indicate appropriate theoretical foundations for leaders' values and beliefs. Considering the amount of literature that described destructive and toxic leadership (Thoroughgood et al., 2018; Smyth, 2017; Webster, 2016) and its impact on cultures and effectiveness, founding leaders' values on authentic and relational leadership theories should be important. This will also be an aspect worth further exploration in later stages of our study.

In this most recent review contextual commentaries highlighted the ubiquitousness of technology and the importance of a range of 

6(2), June 2021, 378-430

technologies to universities. This has been further illustrated throughout the COVID-19 crisis where universities have had to move their teaching, research, supervision, and daily operations into online delivery platforms. Even so, there was no discussion of technologies to support leaders' development. This appears to be an interesting omission given a) how universal technology is, b) the opportunities for privacy, confidentiality, and individualized support, and c) the flexibility of being able to access LD how and when it is convenient to the leader. Hence, it will be interesting to explore if there is leaderreceptivity to engaging in $\mathrm{LD}$ through a technological delivery interface, and if so, what types, content, or approaches would be conducive? Alternatively, if not, why not?

\section{Conclusion}

The findings from this literature review have provided a useful update to our previous literature review (Scott et al., 2016b). It also provided useful insights into leadership and LD in Latin American in preparation for our study to commence in Chile and potentially in other Latin American contexts. We will also be drawing upon the insights offered in these literature reviews to inform the development of subsequent questionnaires and interview instruments which are planned for the next stage of our research - surveys with university leaders. We anticipate that the literature review and surveys will subsequently inform our recommendations for LD programs to ensure maximum pragmatics, and potentially, inform theoretical contributions to the HE field of study.

With the background presented in this paper, we identified there has been a shift in the functions that universities and that leaders must have different skills to equip them for leadership in these complex environments. We also observed there was 
considerable alignment across different countries in terms of the challenges that leaders face, although we will remain mindful to explore the important cultural differences and institutional nuances that may emerge. There was also a general agreement that academic leaders needed leadership preparation and development to ensure they had the necessary skills to be successful. We also observed that there was a series of skills that university leaders must have for success and effectiveness.

Taking all of this into consideration, our projected next steps will be to engage leaders (at different levels in universities) to identify their perspectives about what they want and need in LD, and then to recommend and/or establish LD programming that meets these expectations. However, from this literature review there was insufficient consensus to establish a priority list of content and what delivery formats were optimal and why. Hence, the next stages of the project - surveys and interviews with leaders in each participating country - will be essential to exploring from a personal perspective what LD is optimal for leaders.

\section{References}

Acker, S. (2014). A foot in the revolving door? Women academics in lower-middle management. Higher Education Research $\mathcal{E}$ Development, 33(1), 73-85. https://doi.org/10.1080/07294360.2013.864615

Alghamdi, S. A., Abuznadah, W., \& Ahmed, A. A. (2016). Academic Leadership Development (ALD) program at college of medicine, Jeddah; King Saud bin Abdulaziz University for Health Sciences, Middle East Journal of Family Medicine, 14(1), 4-14. 

6(2), June 2021, 378-430

Almayali, H. H., \& Ahmad, Z. A. B. (2012). Leadership behaviours and academic performance in Iraqi public universities: A review. Information Management and Business Review, 4(12), 596-600.

Alstete, J. W. (2014). Revenue generation strategies: Leveraging higher education resources for increased income. Wiley.

Apple, M. W. (2000). Between neoliberalism and neoconservatism: Education and conservatism in a global context. In N. Burbules \& C. Torres (Eds.), Globalization and education: Critical perspectives (pp. 57-78). Routledge. https://doi.org/10.1207/s15544818ped0101_4

Apple, M. W. (2006). Understanding and interrupting neoliberalism and neoconservatism in education. Pedagogies: An International Journal, 1(1), 21-26. https://doi.org/10.1207/s15544818ped0101_4

Apple, M. W. (2013). Audit cultures, labour, and conservative movements in the global university. Journal of Educational Administration and History, 45(4), 385-394. https://doi.org/10.1080/00220620.2013.822349

Apple, M. W. (2017). What is present and absent in critical analyses of neoliberalism in education. Peabody Journal of Education, 92(1), 148-153. http://dx.doi.org/10.1080/0161956X.2016.1265344

Aristimuño, M., \& Guaita, W. (2018). Las competencias gerenciales en la gestión de instituciones de educacion superior. Posgrado y Sociedad, 11(2), 66-81. https://doi.org/10.22458/rpys.v11i2.2224

Avolio, B. J., \& Gardner, W. L. (2005). Authentic leadership development: Getting to the root of positive forms of leadership. The Leadership Quarterly, 16(3), 315-338. https://doi.org/10.1016/j.leaqua.2005.03.001 
Baartman, I. (2011). Professional leadership experiences with formal and informal mentoring of college deans of education at 4-year nonprofit private colleges and universities in California [Ed.D., University of La Verne]. ProQuest Dissertations \& Theses Global. Ann Arbor.

Beard, S. (2020). UK universities stand to lose billions if the pandemic keeps foreign students away. Marketplace. https://www.marketplace.org/2020/05/12/covid-19-unitedkingdom-universities-international-students/

Berbegal-Mirabent, J., Sánchez García, J. L., \& Ribeiro-Soriano, D. E. (2015). University-industry partnerships for the provision of R\&D services. Journal of Business Research, 68(7), 1407-1413. https://doi.org/10.1016/j.jbusres.2015.01.023

Bradley, A. P., Grice, T., \& Paulsen, N. (2017). Promoting leadership in Australian universities. Australian Universities' Review, 59(1), 97-105.

Bratianu, C., \& Pinzaru, F. (2015). University governance as a strategic driving force. Proceedings of the European Conference on Management, Leadership \& Governance, (pp. 28-35).

Carballo, M. A. L. (2019). Incentivo del liderazgo compartido en la educación superior. Dominio de las Ciencias, 5(1), 385-400. https://doi.org/10.23857/dc.v5i1.868

Cardiel, H. C. (1999). Educacion superior en América Latina: Políticas y gobierno. Revista Española de Educación Comparada (5), 155-176.

Carrick Institute for Learning and Teaching in Higher Education. (2008). "Caught between a rock and several hard places" Cultivating the roles of the Associate Dean (Teaching and Learning) and the Course Coordinator. 

6(2), June 2021, 378-430

https://www.researchgate.net/publication/341385166_'Caught_be tween_a_rock_and_several_hard_places'_Cultivating_the_roles_ of_the_Associate_Dean_Teaching_and_Learning_and_the_Cours e_Coordinator_A_report_for_the_Carrick_Institute_for_Learning _and_Teachin

Choudhary, M., \& Paharia, P. (2018). Role of leadership in quality education in public and private higher education institutions: A comparative study. GYANODAYA: The Journal of Progressive Education, 11(1), 17-24.

Cifuentes, G., \& Vanderlinde, R. (2015). Liderazgo de las TIC en educación superior: Estudio de caso múltiple en Colombia. Comu-nicar, 23(45), 133-141. https://doi.org/10.3916/C45-2015-14

Clark, T. (2009). The impact of reforms on the quality and responsiveness of universities in the United Kingdom. Higher Education Management \& Policy, 21(2), 1-19. http://dx.doi.org/10.1787/hemp-v17-art11-en

Cleverley-Thompson, S. (2016). The role of academic deans as entrepreneurial leaders in higher education institutions. Innovative Higher Education, 41(1), 75-85. https://doi.org/10.1007/s10755-015-9339-2

Commodore, F., Freeman, S., Jr., Gasman, M., \& Carter, C. M. (2016). "How it's done": The role of mentoring and advice in preparing the next generation of historically black college and university presidents. Education Sciences, 6(19), 1-14. https://doi.org/10.3390/educsci6020019

Contreras, F. G., Negrete, G. L., \& Viancos, P. (2018). Caracterización de los cuadros directivos de las universidades chilenas a partir de su formación de pre y post grado. Opción, 34(87), 72-104. 
Cudmore, G. (2005). Globalization, internationalization, and the recruitment of international students in higher education, and in the Ontario Colleges of Applied Arts and Technology. The Canadian Journal of Higher Education, 35(1), 37-60.

Davies, J., \& Thomas, H. (2009). What do business school deans do? Insights from a UK study. Management Decision, 47(9), 1396-1419. https://doi.org/10.1108/00251740910995620

Davies, J., \& Thomas, H. (2010). What do deans do? Global Focus, 4(1), $44-47$.

de la Garza, M. T., Cervantes, A., Guzmán, E., \& Ramos, C. (2017). Características de liderazgo del administrador educativo de las instituciones de educación superior en México. Actualidades Investigativas en Educación, 17(3). https://doi.org/10.15517/AIE.V17I3.29871

de Paor, C. (2016). The contribution of professional accreditation to quality assurance in higher education. Quality in Higher Education, 22(3), 228-241. https://doi.org/10.1080/13538322.2016.1263925

DeBoy, J. L. (2015). When the corporate storm strikes the academy: Faculty response required. Contemporary Issues in Education Research, 8(1), 15-18.

DeFleur, M. H., Kurpius, D. D., Osborne, A., \& Maxwell Hamilton, J. (2010). The masters: Creating a new generation of leaders for mass communication education and beyond. Communication Education, 59(1), 19-40. https://doi.org/10.1080/03634520903311848

DeZure, D., Shaw, A., \& Rojewski, J. (2014). Cultivating the next generation of academic leaders: Implications for administrators 

6(2), June 2021, 378-430

and faculty. Change: The Magazine of Higher Learning, 46(1), 6-12. https://doi.org/10.1080/00091383.2013.842102

Dopson, S., Ferlie, E., McGivern, G., Fischer, M. D., Mitra, M., Ledger, J., \& Behrens, S. (2019). Leadership development in higher education: A literature review and implications for programme redesign. Higher Education Quarterly, 73(2), 218-234. https://doi.org/10.1111/hequ.12194

Doyle, W. R., \& Delaney, J. A. (2009). Higher education funding: The new normal. Change, 41(4), 60-62.

Eastman, J. A. (2006). Revenue generation and organisational change in higher education: Insights from Canada. Higher Education Management \& Policy, 18(3), 1-27. http://dx.doi.org/10.1787/hempv17-art11-en

Erkutlu, H., Chafra, J., \& Bumin, B. (2011). Organizational culture's role in the relationship between power bases and job stress. Hacettepe University Journal of Education, 40, 198-209. http://www.efdergi.hacettepe.edu.tr/english/abstracts/40/pdf/HA KAN\%20ERKUTLU.pdf

Fabela-Cárdenas, M. A., \& García-Treviño, A. H. (2014). Quality management in private higher education. Magis. Revista Internacional de Investigación en Educación, 6(13), 65-82.

Falcón, C. E. (2016). Un nuevo modelo de gerencia y gestión académico administrativo: Para la universidad venezolana. Palermo Business Review (13), 111-129. https://www.palermo.edu/economicas/cbrs/pdf/pbr12/PBR_13_0 7.pdf 
Floyd, A., \& Preston, D. (2018). The role of the associate dean in UK universities: Distributed leadership in action? Higher Education, 75(5), 925-943. https://doi.org/10.1007/ s10734-017-0178-1

Franken, M., Penney, D., \& Branson, C. (2015). Middle leaders' learning in a university context. Journal of Higher Education Policy and Management, 37(2), 190-203. https://doi.org/10.1080/1360080X.2015.1019120

Ganga, F., Rodriguez, E., Navarrete, E., \& Pedraja, L. (2018). Relevancia del liderazgo en el gobierno de las universidades iberoamericanas. Interciencia: Revista de ciencia y tecnología de América, 43(3), 160-167.

Gigliotti, R. A., \& Ruben, B. D. (2017). Preparing higher education leaders: A conceptual, strategic, and operational approach. Journal of Leadership Education, 16(1), 96-114. https://doi.org/10.12806/V16/I1/T1

Gmelch, W. H. (2015). Building academic leadership capacity. JosseyBass.

Gonzalez-Rodriguez, G. I., \& Magaña-Fernández, M. A. (2018). Modernización en la gestión educativa: Características de los líderes en las instituciones de educación superior. Ra Ximhai: revista científica de sociedad, cultura y desarrollo sostenible, 14(3). 8199.

Green, A., \& Ridenour, N. (2004). Shaping a career trajectory in academic administration: Leadership development for the deanship. Journal of Nursing Education, 43(11), 489-495.

Hamlin, R. G., \& Patel, T. (2017). Perceived managerial and leadership effectiveness within higher education in France. 

6(2), June 2021, 378-430

Studies in Higher Education, 42(2), 292-314. https://doi.org/10.1080/03075079.2015.1045480

Hempsall, K. (2014). Developing leadership in higher education: Perspectives from the USA, the UK and Australia. Journal of Higher Education Policy Management,36(4),383-394. https://doi.org/10.1080/1360080X.2014.916468

Herbon, F., \& Vivas, M. Q. (2015). Cambios en la estructura organizacional de las universidades nacionales del conurbano: La emergencia de nuevos roles y funciones. XI Jornadas de Sociología. https://www.aacademica.org/000-061/1165

Hodson, J. B. (2010). Leading the way: The role of presidents and academic deans in fundraising. New Directions for Higher Education, (149), 39-49. https://doi.org/10.1002/he.379

Horn, M. (1999). Tenure and the Canadian professoriate. Journal of Canadian Studies, 34(3), 261-281.

Huerta-Riveros, P., \& Pedraja-Rejas, L. (2019). Planificación y seguimiento Procesos claves para la dirección estratégica de instituciones de educación superior. Interciencia, 44(1), 5-5. https://www.interciencia.net/wp-content/uploads/2019/01/5editorial-es-44-01.pdf

Isaac, C. A., Behar Horenstein, L. S., \& Koro Ljungberg, M. (2009). Women deans: Leadership becoming. International Journal of Leadership in Education, 12(2), 135-153. https://oi.org/10.1080/13603120802485102

Jaffe, A. (2017). Differentiated eliteness: Socialization for academic leadership. Social Semiotics, 27(3), 370-381. https://doi.org/10.1080/10350330.2017.1301801 
Jones, G. A. (2013). The horizontal and vertical fragmentation of academic work and the challenge for academic governance and leadership. Asia Pacific Education Review, 14(1), 75-83. https://doi.org/10.1007/s12564-013-9251-3

Jones, S., Harvey, M., Hamilton, J., Bevacqua, J., Egea, K., \& McKenzie, J. (2017). Demonstrating the impact of a distributed leadership approach in higher education. Journal of Higher Education Policy Management, 39(2), 197-211. https://doi.org/10.1080/1360080X.2017.1276567

Jooste, K., \& Frantz, J. (2017). Self-leadership traits of academics to conform to a changing higher-education environment. African Journal of Health Professions Education, 9(4), 199-202. https://doi.org/10.7196/AJHPE.2017.v9i4.823

Kenner, C. A., \& Pressler, J. L. (2011). Transparency: An essential ingredient to a successful deanship. Nurse Educator, 36(6), 231232. https://doi.org/10.1097/NNE.0b013e3182333cd0

Kleihauer, S., Stephens, C. A., \& Hart, W. E. (2012). Insights from six women on their personal journeys to becoming deans of agriculture: A qualitative study. Journal of Leadership Education, 11(1), 64-83.

Kligyte, G., \& Barrie, S. (2014). Collegiality: Leading us into fantasy The paradoxical resilience of collegiality in academic leadership. Higher Education Research and Development, 33(1), 157-169. https://doi.org/10.1080/07294360.2013.864613

Kouzes, J. M., \& Posner, B. Z. (2012). The leadership challenge: How to make extraordinary things happen in organizations ( $5^{\text {th }}$ ed.). JosseyBass. 
Kouzes, J. M., \& Posner, B. Z. (2019). Leadership in higher education. Berrett-Koehler Publishers, Inc.

Lamm, K. W., Sapp, L., \& Lamm, A. J. (2018). A longitudinal evaluation of change leadership within a leadership development program context. Journal of Leadership Education, 17(3). 121-134. https://doi.org/10.12806/V17/I3/R7

Lopez, R. (2013). Percepciones de académicos, directivos y funcionarios sobre la legitimidad y el liderazgo de los rectores de las universidades públicas mexicanas. Revista mexicana de investigación educativa, 18(58), 811-837. http://www.scielo.org.mx/scielo.php?script=sci_abstract\&pid=S1 405-66662013000300007\&lng=es\&nrm=iso

Maclean, K. (2016). Sanity, "madness", and the academy. The Canadian Geographer, 60(2), 181-191. https://doi.org/10.1111/cag.12264

Maghroori, R., \& Powers, C. (2004). How to choose the right dean for your university: Remembering the five P's of deanship. Change, 36(2), 52-54. https://doi.org/10.2307/40177934

Marginson, S. (2000). Rethinking academic work in the global era. Journal of Higher Education Policy and Management, 22(1), 23-35. https://doi.org/10.1080/713678133

Marginson, S. (2002). The phenomenal rise of international degrees down under. Change, 34(3), 34-43.

Marginson, S. (2003, 29th Nov-3rd Dec). Markets in higher education: National and global competition. NZARE/AARE Joint Conference, Auckland, New Zealand. 
Marginson, S. (2006). Dynamics of national and global competition in higher education. Higher Education, 52, 1-39. https://doi.org/10.1007/s10734-004-7649-x

Marginson, S. (2009). The knowledge economy and Higher Education: A system for regulating the value of knowledge. Higher Education Management \& Policy, 21(1), 1-15. https://doi.org/10.1787/hemp-v21-art3-en

Marginson, S., \& van der Wende, M. (2007a). Globalisation and higher education (OECD Education Working Papers No. 8, Issue 8). http://dx.doi.org/10.1787/173831738240

Marginson, S., \& van Der Wende, M. (2007b). To rank or to be ranked: The impact of global rankings in higher education. Journal of Studies in International Education, 11(3-4), 306-329. https://doi.org/10.1177/1028315307303544

Martin, J. (2015). Transformational and transactional leadership: An exploration of gender, experience, and institution type. Portal: Libraries and the Academy, 15(2), 331-351. https://doi.org/10.1353/pla.2015.0015

Mattar, M., van Nieuwerburgh, C., Barr, M., \& Jacob, Y. (2018). A role for coaching to support leadership development? The experiences of female Arab leaders: An interpretative phenomenological analysis. International Coaching Psychology Review, 13(2), 77-86.

Messier, J. (2017). Shared governance and academic freedom: Yes, this is union work. Thought $\mathcal{E}$ Action, 33(2), 63-76. https://www.nea.org/assets/docs/TA2017S_Messier.pdf

Montez, J., \& Wolverton, M. (2000). The challenge of the deanship. AERA, New Orleans, LA. 

6(2), June 2021, 378-430

Moreno, E. C., \& De Armas, R. (2018). El liderazgo de los directivos de las organizaciones de la educación superior Cubana: Una visión crítica. Estudios del Desarrollo Social: Cuba y America Latina, 7(1). http://www.revflacso.uh.cu/index.php/EDS/article/view/306

Morris, T. L., \& Laipple, J. S. (2015). How prepared are academic administrators? Leadership and job satisfaction within US research universities. Journal of Higher Education Policy and Management, $37(2)$, 241-251. https://doi.org/10.1080/1360080X.2015.1019125

Mysyk, A. (2001). The sessional lecturer as migrant labourer. The Canadian Journal of Higher Education, 31(3), 73-92.

Ngo, J., de Boer, H., \& Enders, J. (2014). The way deans run their faculties in Indonesian universities. Tertiary Education and Management, 20(1), 1-13. https://doi.org/10.1080/13583883.2013.848924

Nica, E. (2013). The importance of leadership development in higher education. Contemporary Readings in Law \& Social Justice, 5(2), 189194.

Nies, C., \& Wolverton, M. (2000, April). Mentoring deans. American Educational Research Association, New Orleans, LA.

Northouse, P. (2019). Leadership: Theory and practice ( $8^{\text {th }}$ ed.). Sage Publications, Inc.

Opstrup, N., \& Pihl-Thingvad, S. (2016). Stressing academia? Stressas-offence-to-self at Danish universities. Journal of Higher Education Policy and Management, 38(1), 39-52. http://dx.doi.org/10.1080/1360080X.2015.1126895 
Ortega, G. P., \& Freites, Z. M. (2017, Jan). Constructo teórico sobre la gerencia universitaria. Criterio Libre, 15(26), 23-42. https://doi.org/10.18041/1900-0642/criteriolibre.2017v15n26.1030

Ortrun, Z.-S., \& Louw, I. (2014). Academic leadership development programs: A model for sustained institutional change. Journal of Organizational Change Management, 27(6), 1008-1024. https://doi.org/10.1108/JOCM-11-2013-0224

Osei-Kofi, N. (2012). Junior faculty of color in the corporate university: Implications of neoliberalism and neoconservatism on research, teaching and service. Critical Studies in Education, 53(2), 229-244. https://doi.org/10.1080/17508487.2012.672326

Packham, C. (2020). Australia scraps plans to allow foreign students back. Reuters.https://www.msn.com/en-sg/news/world/australiascraps-plans-to-allow-foreign-students-back/ar-BB1aY8pX

Thoroughgood, C. N., Sawyer, K. B., Padilla, A., \& Lunsford, L. (2018). Destructive leadership: A critique of leader-centric perspectives and toward a more holistic definition. Journal of Business Ethics, 151(3), 627-649. https://doi.org/10.1007/s10551016-3257-9

Pedraja-Rejas, L., Araneda, C., Bernasconi, A., \& Viancos, P. (2018). Liderazgo, cultura académica y calidad de las universidades: aproximación conceptual y relaciones. Revista Venezolana de Gerencia, 23(1), 184. https://doi.org/10.31876/revista.v23i1.24463

Pounder, J. S. (2001). "New leadership" and university organisational effectiveness: Exploring the relationship. Leadership $\mathcal{E}$ Organization Development Journal, 22(5/6), 281-290. https://doi.org/10.1108/EUM0000000005827 

6(2), June 2021, 378-430

Preston, D., \& Floyd, A. (2016). Supporting the role of associate dean in universities: An alternative approach to management development. Higher Education Quarterly, 70(3), 264-280. https://doi.org/10.1111/hequ.12099

Prosser, M., \& Barrie, S. C. (2000). Using a student-focused learning perspective to strategically align academic development with institutional quality assurance. In R. Blackwell \& P. Blackmore (Eds.), Towards strategic staff development in higher education (pp. 195-202). Open University Press.

Prosser, M., \& Trigwell, K. (1999). Understanding learning and teaching: The experience in higher education. Open University Press.

Rajagopal. (2009). Globalization thrust: Driving nations competitive. Nova Science Publishers Inc.

Ramírez, A., \& Hyslop-Margison, E. (2015). Neoliberalism, universities and the discourse of crisis. L2 Journal, 7(3). https://doi.org/10.5070/127323492

Ramsden, P. (1998). Learning to lead in higher education. Routledge.

Ramsden, P., \& Martin, E. (1996). Recognition of good university teaching: Policies from an Australian study. Studies in Higher Education, 21(3), 299-315.

Raschio, C., Gonzalez, E., Scaffido, G., Marciali, J., \& Moyano, M. (2019). Experiencias de gestión y liderazgo universitario en el siglo XXI: el caso de la UMaza desde las voces de sus actores. En la Mira. La Educación Superior en Debate, 1(1), 50-62. http://repositorio.umaza.edu.ar/ojs/index.php/ enlm/article/view/185

Robinson, N. (2019). Australian universities risk catastrophe due to overreliance on Chinese students, expert warns. ABC News. 
https://www.abc.net.au/news/2019-08-21/australian-universitiestoo-dependent-on-chinese-students-report/11427272

Rodriguez-Videla, L. (2018). Exploring issues of quality teaching and learning within public Chilean higher education [PhD. University of Calgary]. Alberta, Canada.

Rosser, V. J., Johnsrud, L. K., \& Heck, R. H. (2003). Academic deans and directors: Assessing their effectiveness from individual and institutional perspectives. The Journal of Higher Education, 74(1), 125. https://doi.org/10.1353/jhe.2003.0007

Ruben, B. D., De Lisi, R., \& Gigliotti, R. A. (2018). Academic leadership development programs: Conceptual foundations, structural and pedagogical components, and operational considerations. Journal of Leadership Education, 17(3). 241-254.

Sanchez, M. M. (2016). Gestión del cambio y planificación estratégica: En instituciones de educación. Palermo Business Review, (13), 5172.

http://www.palermo.edu/economicas/cbrs/pdf/pbr12/PBR_13_04. pdf

Scholkmann, A. (2011). Deans in German universities: Goal acceptance and task characteristics. Tertiary Education and Management, 17(4), 337-353. https://doi.org/10.1080/13583883.2011.601752

Scott, S., Scott, D. E., Dudar, L., \& Anne, A. (2016a, 27 November-1 December). Middle level academic leadership has changed dramatically over the past decade: Insights from senior university leaders. Australian Association for Research in Education (AARE) conference, Melbourne, Australia. 

6(2), June 2021, 378-430

Scott, S., Scott, D. E., Dudar, L., Anne, A., \& Dixon, K. C. (2016b, 28 May-1 June). Understanding universities and the complexities of formal academic leadership: A review of the literature. The Canadian Association for Studies in Educational Administration (CASEA CSSE) conference, Calgary, Canada.

Seale, O., \& Cross, M. (2016). Leading and managing in complexity: The case of South African deans. Studies in Higher Education, 41(8), 1514-1532. https://doi.org/10.1080/03075079.2014.988705

Shahmandi, E., Silong, A. D., Ismail, I. A., Samah, B. B. A., \& Othman, J. (2011). Competencies, roles and effective academic leadership in world class university. International Journal of Business Administration, 2(1), 44. https://doi.org/10.5430/ijba.v2n1p44

Shahmandi, E., Silong, A., \& Ismail, L. (2012). Level of competencies, gender and leadership effectiveness in a research university. Management Research and Practice, 4(1), 63-73.

Smyth, J. (2017). The toxic university. Zombie leadership, academic rock stars, and neoliberal ideology. Palgrave McMillan.

Söderhjelm, T., Björklund, C., Sandahl, C., \& Laksov, B. K. (2018). Academic leadership: Management of groups or leadership of teams? A multiple-case study on designing and implementing a team-based development programme for academic leadership. Studies in Higher Education, 43(2), 1-16. https://doi.org/10.1080/03075079.2016.1160277

Stensaker, B., \& Vabø, A. (2013). Re-inventing shared governance: Implications for organisational culture and institutional leadership. Higher Education Quarterly, 67(3), 256-274. https://doi.org/10.1111/hequ.12019 
Tang, K., Ariratana, W., \& Treputharan, S. (2013). Perceived leadership soft skills and trustworthiness of deans in three Malaysian public universities. Educational Research for Policy and Practice, 12(3), 211-224. https://doi.org/10.1007/s10671-013-9142-8

The Quality Assurance Agency for Higher Education (U.K.). The UK's Quality Body for Higher Education. https://www.qaa.ac.uk/en\#

Toakley, A. R. (2004). Globalization, sustainable development and universities. Higher Education Policy, 17(3), 311-324. https://doi.org/10.1057/palgrave.hep.8300058

Torres, E. H., \& Torres, G. C. (2015). La gestión mecanicista de las Instituciones de Educación Superior: Un estudio desde la modelación sistémica. Contaduría y Administración, 60(4), 796-816. https://doi.org/10.1016/j.cya.2014.05.001

Trigwell, K., \& Prosser, M. (1991). Improving the quality of student learning: The influence of learning context and student approaches to learning on learning outcomes. Higher Education, 22(3), 251-266. https://doi.org/10.2307/3447175

Universities UK. (2016). Working in partnership: Enabling social mobility in higher education. The final report of the Social Mobility Advisory Group. https://www.universitiesuk.ac.uk/policy-andanalysis/reports/Pages/working-in-partnership-enabling-socialmobility-in-higher-education.aspx

Vatanartiran, S. (2013). Challenges in the establishment of a new faculty: Experiences of the founding deans and faculty members. Eurasian Journal of Educational Research, (52), 169-188.

Vega, R. B., Espinosa, A. B., \& Krücken, G. (2015). Liderazgo de los rectores frente a la "tercera misión" de la universidad: visiones 

6(2), June 2021, 378-430

globales, miradas locales. Revista Mexicana de Investigación Educativa, 20(65), 393-417.

Vilkinas, T., \& Ladyshewsky, R. K. (2014). Factors impacting job performance and role attractiveness in academic directors and their implications for policy and practice in higher education. Educational Research for Policy and Practice, 13(2), 101-114. https://doi.org/10.1007/s10671-013-9153-5

Wang, V. C., \& Sedivy-Benton, A. L. (2016). Leadership misplacement: How can this affect institutions of higher education? New Horizons in Adult Education and Human Resource Development, 28(3), 14-25. https://doi.org/10.1002/nha3.20148

Watts, J., \& Robertson, N. (2011). Burnout in university teaching staff: A systematic literature review. Educational Research, 53(1), 33-50. https://doi.org/10.1080/00131881.2011.552235

Webber, C. F., \& Scott, S. (2013). Principles for principal preparation. In C. L. Slater \& S. Nelson (Eds.), Understanding the principalship: An international guide to principal preparation (Vol. 19, pp. 95-124). Emerald. https://doi.org/10.1108/S1479-3660(2013)000001900973

Webber, C. F., \& Scott, S. (2008). Entrepreneurship and educational leadership development: A Canadian and Australian perspective. International Electronic Journal in Leadership Learning, 12(11), n.p.

Webber, C. F., Scott, S., \& Scott, D. E. (2014). Three orders of leadership development: Abecedarian to Manager to Entrepreneur. International Journal of Leadership in Learning, 1(2), 1-39. 
Webster, V., Brough, P., \& Daly, K. (2016). Fight, flight or freeze: Common responses for follower coping with toxic leadership. Stress and Health, 32(4), 346-354. https://doi.org/10.1002/smi.2626

Weerts, D. J., \& Sandmann, L. R. (2010). Community engagement and boundary-spanning roles at research universities. Journal of Higher Education, 81(6-), 702-727.

Werner, D. (2009). On the dark side: Lessons learned as interim dean. In E. E. Englehardt, M. S. Pritchard, K. D. Romesburg, \& B. Schrag (Eds.), The ethical challenges of academic administration (pp. 37-47). Springer.

Wilkes, L., Cross, W., Jackson, D., \& Daly, J. (2015). A repertoire of leadership attributes: an international study of deans of nursing. Journal of Nursing Management, 23(3), 279-286. https://doi.org/10.1111/jonm.12144

Wolverton, M., \& Gonzales, M. J. (2000, April). Career paths of academic deans. American Educational Research Association, New Orleans.

Wolverton, M., \& Poch, S. (2000). The nexus between academic deans and corporate CEOs: An opportunity in the making AERA, New Orleans.

Wolverton, M., Ackerman, R., \& Holt, S. (2007). Preparing for leadership: What academic department chairs need to know. Journal of Higher Education Policy and Management, 27(2), 227-238. https://doi.org/10.1080/13600800500120126

Wolverton, M., Gmelch, W. H., Montez, J., \& Nies, C. T. (2001). The changing nature of the academic deanship (Vol. 28). ASHE-ERIC Higher Education Report. https://doi.org/10.1177/1742715009337765

Wolverton, M., Wolverton, M. L., \& Gmelch, W. H. (1998). The interconnections between job satisfaction and work-related stress in 

6(2), June 2021, 378-430

academic deans. American Educational Research Association, San Diego.

Wyman, M. (1973). Tenure, tenure procedures and sabbatical leave. Queen's Quarterly, 80(1), 12.

\begin{abstract}
About the authors
Fernanda Kri is the Provost at O'Higgins University in Chile. Prior to 2020 she was full Professor in the University of Santiago of Chile, where she has previously been Provost and Vice-Chancellor of Academic Affairs. Her experience includes roles in the Chilean Ministry of Education. She has led projects in higher education as quality assurance, curriculum innovation and equity in access.

E-mail: fernanda.kri@usach.cl
\end{abstract}

Authorship credit details: Conceptualization of paper, methodology - thematic analysis, writing, draft preparation.

Shelleyann Scott is a Professor in Leadership, Policy \& Governance, University of Calgary, Canada. Shelleyann has international experience as an educator, leader, and professional developer across 15 countries. Her research is in leadership development in schools and universities. Her leadership roles include: district curriculum leadership, associate dean, director, and coordinator roles in universities.

Email: sscott@ucalgary.ca

Authorship credit details: Conceptualization of paper, writing, draft preparation, editing and reviews.

Donald E. Scott is an Associate Professor in Leadership, Policy \& Governance, University of Calgary, Canada. Don has 40 years of teaching and administration experience in schools and universities. 
Don's research includes: leadership development, capacity building, and quality teaching and learning in higher education. He is the chair/member of numerous awards committees which recognize research excellence.

Email: descott@ucalgary.ca

Authorship credit details: Researching, writing, draft preparation, formatting, APA checks/formatting, editing and reviews. 

6(2), June 2021, 378-430

\section{Appendix A - Contemporary Universities Contexts and Leadership Roles}

\section{Contemporary Universities' New Functions and Leadership Roles}

New financing mechanism; Increase in the number of diverse students; Quality assurance and accountability system; Globalization and internationalization; Use of technologies; Strategic planning, monitoring and evaluation; Networking; Ranking improvement; Decision-making responsibilities.

\begin{tabular}{ll}
\hline Latin American & (Carballo, 2019), (Cardiel, 1999), (Cifuentes \& \\
& Vanderlinde, 2015), (Herbon \& Vivas, 2015), (Huerta- \\
& Riveros \& Pedraja-Rejas, 2019), (Lopez, 2013) (Ortega \& \\
& Freites, 2017), (Sanchez, 2016), (Vega et al., 2015). \\
\hline Non-Latin & (Bradley et al., 2017), (Cleverley-Thompson, 2016), (de \\
American & Paor, 2016), (Floyd \& Preston, 2018), (Gigliotti \& Ruben, \\
& 2017), (Hempsall, 2014), (Jones et al.,2017), (Jones, 2013), \\
& (Lamm et al., 2018), (Morris \& Laipple, 2015), (Preston \& \\
& Floyd, 2016), (Ruben et al., 2018), (Wang \& Sedivy- \\
& Benton, 2016)
\end{tabular}




\section{Appendix B - Essential Leadership Skills and Capacities}

\section{Comparing Pragmatic and Theoretical Research in Latin American and Non-Latin} American Literature

\section{Case Studies}

Relationship and trust-building, team-building and team-working, empathy, communication skills, decision-making, difficult decision making, conflict management, visioning, networking, marketing, contextual insights, navigating competing interests of different stakeholder groups, ability to influence peers, ability to set clear expectations, technological leadership, consistency and meets commitments, proactivity, prioritization, flexibility and adaptability to change, diagnosis of need and direction, understand de context, understand culture, self-organization, work constructively.

Latin American

(Cifuentes and Vanderlinde, 2015), (de la Garza et al., 2017), (Fabela-Cárdenas and Garcia-Treviño, 2014), (Ganga et al., 2018), (Gonzalez-Rodriguez, 2018), (Raschio et al., 2019), (Torres and Torres, 2015).

Non-Latin American

(Franken et al.,2015), (Hempsall, 2014), (Vilkinas \& Ladyshewsky, 2014), (Morris and Laipple, 2015), (CleverleyThompson, 2016), (Söderhjelm et al., 2018), (Alghamdi et al., 2016, Choudhary \& Paharia, 2018), (Jooste \& Frantz, 2017), (Ngo et al., 2014)

\section{Theoretical}

Strategic planning and management, managing tensions, balance in administration and academic activities, shared and transformational leadership, navigating academic and nonacademic staff interests

\begin{tabular}{ll}
\hline Latin American & $($ Carballo, 2019), (Falcón, 2016), (Ortega \& Freites, 2017), \\
& $($ Pedraja-Rejas, Araneda, Bernasconi, \& Viancos, 2018), \\
& $($ Sanchez, 2016). \\
\hline Non-Latin American & $($ Bradley et al., 2017), (Odhiambo, 2014) \\
\hline
\end{tabular}




\section{Appendix C - Leadership Development Findings}

Leadership Development - Latin American and Non-Latin

American Literature

General characteristics:

Adjusted to the need of each leader, Contextualized to each institution, Mentoring and coaching, Learning on-the-job.

Specific subject:

Budgetary training, University organization procedures, Conflict management, Leading and managing staff, Team working, Effective communication, Leading change, Collaboration, Entrepreneurship, Networking, Time management.

Non-Latin

(Alghamdi et al., 2016), (Bradley et al., 2017), (Dopson et

American al., 2019); (Floyd \& Preston, 2018), (Franken et al., 2015), (Gigliotti \& Ruben, 2017), (Hamlin \& Patel, 2017), (Hempsall, 2014), (Jaffe, 2017), (Lamm et al., 2018), (Mattar et al., 2018), (Morris \& Laipple, 2015), (Preston \& Floyd, 2016), (Ruben et al., 2018), (Seale \& Cross, 2016), (Stensaker \& Vab, 2013).

Latin American (Aristimuño \& Guaita, 2011), (Moreno \& De Armas, 2018) 